\title{
Catching Up: The Role of Demand, Supply and Regulated Price Effects on the Real Exchange Rates of Four Accession Countries
}

\author{
Ronald MacDonald ${ }^{1}$ and Cezary Wójcik ${ }^{2}$
}

\begin{abstract}
The main aim of this paper is to examine the exchange rate behavior of a group of four transitional, EU accession countries, with a view to making policy recommendations regarding their accession to full European Monetary Union. We employ a dynamic OLS panel estimator to investigate the relative importance of demand and supply influences on the exchange rates of these countries. Our analysis shows that both supply- and demandside effects are important for the accession countries, although their overall effect on inflation differentials and competitiveness seems to be small. An additional focus of the paper is the examination of the role that administrated, or regulated, prices and the productivity of the distribution sector play in the real exchange rate dynamics. Based on a unique database we show that administrated prices have been a powerful force behind price and real exchange developments for our group of accession countries. The distribution sector is shown to have an independent effect on the internal price ratio overand-above that generated by the BS effect.
\end{abstract}

JEL-Codes: F3, F36.

Keywords: Exchange rates, Monetary Integration, EMU.

$1 \quad$ Ronald MacDonald is a professor at Strathclyde University, Glasgow.

2 Cezary Wójcik is an assistant professor at the Polish Academy of Sciences and the Warsaw School of Economics.

We would like to thank Jarko Fidrmuc for his help and suggestions. Our debt to him goes beyond the usual acknowledgements, as he influenced our work from the outset of this research. Many thanks for helpful comments and suggestions also go to Peter Backé, Franz Schardax, Thomas Reininger, Harmen Lehment as well as the participants of the seminars at the Oesterreichische Nationalbank, at The Vienna Institute for International Economic Studies and the ASP seminar at the Kiel Insitute of World Economics.

We are particularly grateful to Martti Randveer from the Eesti Pank, András Simon from Magyar nemzeti bank, Miroslav Beblavy, Tomas Holly and Mariana Lisa from the National Bank of Slovakia, Uros Čufer and Zemva Mojca from Národná Banka Slovenska as well as Andrej Flajs, Karmen Hren, Milena Jankovic, Natasa Zidar, Bozidara Benedik from the Statistical Office of Slovenia for providing us with the data sets. Many thanks go also to Andreas Nader (OeNB) for excellent statistical support. 


\section{Introduction}

In October 2002 the European Commission indicated that it saw no further barriers to a group of CEEC countries becoming full members of the European Union (EU). Such membership, in turn, requires a commitment to Economic and Monetary Union (EMU). Current EU arrangements imply that the move to monetary union for the accession countries should be a two-stage process, with countries participating in ERM II for (at least) two years before joining the euro area. Therefore once the accession countries have gained entry to the $\mathrm{EU}$, one of the key issues, perhaps the key issue, facing these countries is at what point and at what exchange rate they should enter ERM II. Should they, for example, wait until they have reached a high degree of convergence with respect to key economic indicators, such as inflation or real growth, or should they enter ERM II contemporaneously with their membership in the EU? Some commentators (see for example Gros, 2001) have argued that real convergence should not be an obstacle to a rapid movement to ERM II and, indeed, full monetary union for the accession countries. The argument is that since convergence is likely to be a supply-side phenomenon, it is unlikely to affect the accession countries' competitiveness (this is discussed in more detail below). In contrast, others (see for example MacDonald, 2001) have issued a cautionary note that economic convergence should be addressed prior to participation in EMU. The latter argument is based on the degree of catching-up the accession countries face, which is very different to the experience of previous accession countries.

The issue of catching-up arises because CEEC accession countries' GDP per capita (calculated using PPP weights) is only around USD 8,638 compared to the current EU average of approximately USD 22,303 (in 1999) ${ }^{3}$, implying that the accession countries' per capita GDP would have to grow by about $160 \%$ to reach the EU level. Of course, catching up with the EU average is the raison d'être for the accession countries' participation in EU. However, the catching-up process will necessarily have implications for the participating countries' inflation, which in turn could have important implications for competitiveness, especially if a country aims for a rigid locking of its exchange rate. Such inflationary consequences will, of course, also have a significance for the ability of the country to meet the Maastricht criterion for inflation (set at no more than 1.5 percentage points above the average rate of inflation of the three EU Member States with the lowest inflation). However, proponents of a relatively fast entry to EMU stress that the inflationary pressures generated by the catching-up

$3 \quad$ MacDonald (2001). 
process are likely to be benign, because they are viewed as emanating from the supply side in the form of the Balassa-Samuelson effect. Although such supply-side effects are likely to be important for the accession countries, it seems highly likely that demand-side influences will also be important determinants of inflation differentials and, as we shall argue in this paper, such demand-side effects are likely to have a deleterious effect on inflation and competitiveness.

The main purpose of the present paper is to examine econometrically the relative importance of demand- and supply-side effects on the internal price ratios, and CPIbased real exchange rates, of a group of four accession countries.4 One of the key novelties in our work is that we build new measures of demand- and supply-side effects. For example, previous studies proxied the Balassa-Samuelson effect using the ratio of output to employment in industry (see for example Halpern and Wyplosz, 1997, 2001 and Égert, 2002), and demand-side influences have been captured using GDP per capita and the acceleration of inflation (Halpern and Wyplosz, 2001). Here we also use the ratio of output to employment as our chosen measure of productivity, but we build this measure from output and employment in the traded sector. We also use new demand-side factors, namely private and government consumption.

Additionally, we attempt to calculate the effect of regulated prices on the internal price ratios and $\mathrm{CPI}$-based real exchange rates of our group of accession countries. Such prices are likely to be important, given that they still have a share of between $13 \%$ and $24 \%$ of the accession countries' consumer goods basket. We try to quantify how important these prices are for real exchange rates relative to the demand and supply influences discussed above. Finally, we attempt to measure the influence of the distribution sector on the internal price ratios and on the CPI-based real exchange rates. MacDonald and Ricci (2001) have demonstrated, for example, that total factor productivity from the distribution sector can have a statistically significant effect on the real exchange rate which behaves much like a Balassa-Samuelson effect but coexists with this effect and is not a proxy for it. Since a considerable proportion of the current inward foreign direct investment in the accession countries is aimed at their distribution sector, we believe that analyzing this effect separately is an important element in understanding the behavior of these countries' exchange rates.

The outline of the remainder of this paper is as follows. In the next section we present a motivational overview of the influence of demand- and supply-side effects on real

4 Our choice of countries reflects the availability of data rather than any form of self-selection bias. 
exchange rates and also survey the extant empirical literature on the BalassaSamuelson effect. In section 3 the data set used for our econometric tests is presented, along with our econometric tests. Section 4 contains our empirical results. Section 5 concludes.

\section{Catching Up and Demand and Supply Influences on Real Exchange Rates}

A useful way of thinking about the sources of systematic movements in real exchange rates is to consider the following decomposition of the real exchange rate. As usual, we define the logarithm of the (CPI-based) real exchange rate as:

$$
q_{t} \equiv s_{t}-p_{t}+p_{t}^{*}
$$

where $q$ represents the real exchange rate, $s$ is the nominal exchange rate, $p$ is the overall price measure (the $\mathrm{CPI}$ ), an asterisk denotes a foreign variable and lower-case letters denote natural logarithms. These overall prices may be decomposed into traded and nontraded components as:

$$
\begin{aligned}
& p_{t}=\alpha_{t} p_{t}^{T}+\left(1-\alpha_{t}\right) p_{t}^{N T}, \\
& p_{t}^{*}=\alpha_{t}^{*} p_{t}^{T^{*}}+\left(1-\alpha_{t}^{*}\right) p_{t}^{N T^{*}},
\end{aligned}
$$

where $p_{t}^{T}$ denotes the price of traded goods, $p_{t}^{N T}$ denotes the price of nontraded goods and the $\alpha$ s denote the share of traded goods in the economy. A similar relationship to (1) may be defined for the price of traded goods as:

$$
q_{t}^{T} \equiv s_{t}-p_{t}^{T}+p_{t}^{T^{*}},
$$

By substituting (2) into (3), we may obtain our desired decomposition of the real exchange rate as:

$$
q_{t}=q_{t}^{T}+q_{t}^{T, N T}
$$

where $q_{t}^{N T, T}=\left(\alpha_{t}-1\right)\left(p_{t}^{N T}-p_{t}^{T}\right)+\left(\alpha_{t}-1\right)\left(p_{t}^{N T^{*}}-p_{t}^{T^{*}}\right)$ is the so-called internal price ratio, the relative price of nontraded to traded goods in the home country relative to the foreign country. What are the factors driving these two components of the real exchange rate? Consider, first, the internal price ratio, $q_{t}^{T, N T}$.

In the traditional Balassa-Samuelson approach to understanding systematic movements in the real exchange rate (see for example De Gregorio, Giovannini and Wolf, 1994) productivity shocks in the traded sector are the key force driving the internal price ratio and, ultimately, the CPI-based real exchange rate. The key assumptions in the Balassa-Samuelson approach is that the law of one price (LOOP) 
holds and therefore $q_{t}^{T}$ is zero, or constant, production technology is Cobb-Douglas, with constant returns to scale, and there is some mechanism equalizing wages between the traded and nontraded sectors. With these assumptions it is then straightforward to demonstrate that a positive shock to total factor productivity in the traded sector raises the average wage in the economy, the relative price of nontraded to traded goods rises, and the CPI-based real exchange rate appreciates. Hence the Balassa-Samuelson prediction is that there should be a positive (negative) relationship between total factor productivity in the traded (nontraded) sector and the CPI-based real exchange rate, and the coefficient should be equal to the share of expenditure on nontraded goods.

A second supply-side influence on the internal price ratio involves relative factor endowments. In the traditional Hecksher-Ohlin two factor, two good relative factor endowments model, nontraded (traded) goods are assumed to be relatively laborintensive (capital-intensive) in production. High per capita-income countries are assumed to have a comparative advantage in producing commodities, so the relative price of nontraded goods will be higher in countries with relatively high per capita income.

The influence of demand, of both the public and private sector, on the internal price ratio has been highlighted by Dornbusch (1988), Neary (1988) and Bergstrand (1991). As a country catches up and income rises, demand-side factors can affect the internal price ratio if preferences are nonhomothetic. Usually preferences are thought to be biased in favor of the nontraded good because services are viewed as superior goods. In this case, of course, the demand-side influences would reinforce the supply-side effects, and although this may be thought of as an equilibrium relationship, there may be policy issues in the short to medium run for an accession country wishing to avoid excessive inflationary consequences. Of course, the policy implications of demandside effects are likely to be more pronounced if preferences are skewed in favor of traded goods.

Starting with Bergstrand (1991), a number of studies have sought to capture both the demand- and supply-side influences on the real exchange rate using GDP per capita. For example, Bergstrand (1991) has demonstrated that over $80 \%$ of the crosssectional variation of real exchange rates can be explained by per capita GDP and a constant, and that a $1 \%$ increase in per capita GDP produces a $0.5 \%$ increase in the real exchange rate (or the inflation differential). Slok and De Broek (2000) have 
demonstrated that a similar relationship also holds for the current group of accession countries.

As we have seen, an essential component of the Balassa-Samuelson hypothesis is that the LOOP holds continuously and that $q_{t}^{T}$ is constant or zero. However, the broad thrust of the empirical evidence for developed countries is that the LOOP in fact does not hold. This is evident from studies which focus explicitly on testing the LOOP (see, for example, Isard, 1977) and also studies which examine the decomposition of the CPI-based real exchange rate. For example, Engel (1993) and Rogers and Jenkins (1995) have shown that for developed countries the variability of $q_{t}^{T}$ always dominates the variability of $q_{t}^{T, N T}$. There are a number of interpretations for this finding, such as the importance of sticky prices (see for example Mussa, 1986), the pricing-to-market behavior of firms (see Betts and Devereux, 1996), the importance of transaction costs in imparting nonlinear adjustment to $q_{t}^{T}$ (see Obstfeld and Taylor, 1997), or the imperfect substitutability of traded goods across countries (see MacDonald and Ricci, 2002). Although all of the foregoing arguments seem plausible, the issue of imperfect substitutability seems especially so, given that casual empiricism suggests that goods entering international trade are imperfectly substitutable: a 3 series BMW produced in Germany, for example, is not a prefect substitute for, say, a Ford Mondeo produced in the UK. Indeed, for white goods such as refrigerators, which appear to be very similar across brands and countries, it is well know that even within Europe such items are highly differentiated to appeal to different tastes in different countries.

Of course, even if $q_{t}^{N T, T}$ is the dominant component in explaining real exchange rate variability, this does not necessarily mean that Balassa-Samuelson effects are unimportant. A number of studies have examined the impact of productivity in the traded and nontraded sectors on the real exchange rate. For example, using the OECD sectoral data base to construct measures of total factor productivity (TFP), Chinn and Johnston (1999) demonstrate for the U.S. dollar bilateral exchange rates of a set of developed countries that the Balassa-Samuelson terms are correctly signed and statistically significant with a point estimate close to 0.8. MacDonald and Ricci (2001) confirm this result for a similar panel of countries, although they show that once the productivity terms enter unconstrained, the coefficients are not equal and opposite from the prediction of the Balassa-Samuelson proposition. Furthermore, when wages enter as a conditioning variable in addition to the Balassa-Samuelson term, the coefficient on TFP in the traded sector becomes statistically negative rather than zero as predicted. MacDonald and Ricci (2001) also show that the distribution sector 
behaves much like the effect of productivity on the real exchange rate and should therefore not be included in the nontraded sector, by contrast to what has been assumed in other studies.

MacDonald and Ricci (2002) present an alternative theory of how productivity effects impact on real exchange rates, which helps to explain the seemingly perverse effect productivity has once the real exchange rate has been conditioned on relative wages. The starting point of this new approach is a model based on the so-called new trade theory of Helpman and Krugman (1985). This has at its core product differentiation and a love of variety: in contrast to the standard neoclassical trade theory underpinning the Balassa-Samuelson effect, the imperfect substitutability of traded goods is a sine qua non in this approach. MacDonald and Ricci demonstrate, inter alia, that the coefficient on the productivity of tradables should be smaller in the presence of imperfectly substitutable traded goods and a home bias in favor of home goods. This differs from the Balassa-Samuelson effect, where the coefficient on productivity in nontradables should be equal and opposite relative to the coefficient on productivity in the tradable sector. Additionally, when the wage enters the exchange rate relationship as a conditioning variable, the regression coefficient on productivity in the tradable sector can become significantly negative (because of the imperfect substitutability of traded goods).

A number of studies have quantified the Balassa-Samuelson effect, and also demandside effects, for the current group of accession countries. The first study to estimate the effects of productivity for transitional economies is that of Halpern and Wyplosz (1997), who use a reduced-form approach to capture the effects of productivity and other measures of economic effectiveness on the real exchange rates of a panel of 80 countries (the countries in the panel fall into the following panel groupings: OECD countries, Africa, Southeast Asia, Latin America and transition economies). Halpern and Wyplosz are able to distinguish between these different groupings using fixed and random effects estimators. The productivity measure is average productivity (i.e. they do not distinguish between productivity in the tradable and nontradable sectors), and this is captured by GDP per worker. Their measure of aggregate average productivity produces a large and significant coefficient, which is shown to be sensitive to the inclusion of regional and country dummies - it declines quite dramatically as such dummies are added in. Conversely, the coefficient on investment in human capital (proxied using secondary school enrollment) rises as the regional and country dummies are introduced. They also find that a $10 \%$ decline in the size of agriculture relative to industry increases the dollar wage by between $1 \%$ and $2 \%$. A $10 \%$ increase 
in the size of the government raises wages by $3 \%$ to $6 \%$. This effect is interpreted as measuring the effect of public services and infrastructure on aggregate productivity. Halpern and Wyplosz (2001) focus more directly on the Balassa-Samuelson effect, using a panel data set for nine transition countries over the period 1991-99. Their measure of productivity in the tradable sector is taken to be the ratio of industry output to employment, while the measure of productivity in the nontradable sector is taken to be the ratio of output to employment in the service sector. Their panel regressions involve regressing the relative price of the service sector to the industry price onto the two productivity measures and the two demand-side proxies, namely PPP-adjusted GDP per capita and the change in the rate of inflation. The productivity terms enter with the correct signs and are both statistically significant. The coefficient on productivity in the industry sector is 0.24 , that for the coefficient on productivity in the service sector is -0.18 . GDP per capita also entered with a small, though positive, coefficient; the inflation effect did not have a clear-cut impact on the internal price ratio. Halpern and Wyplosz demonstrate that their results are robust to a number of different estimation methods and that the Balassa-Samuleson effect is strongest in a regime of floating exchange rates.

Égert (2002) examines the Balassa-Samuelson effect for the Czech Republic, Hungary, Poland, Slovakia and Slovenia over the first quarter of 1991 to the second quarter of 2001. The productivity measure used is the ratio of the index of industrial production to employment in that sector (productivity in nontradables is set to zero, as no data are available). As in Halpern and Wyplosz, the industrial sector proxies the traded sector while the service sector represents the nontraded sector. The relative price of nontraded goods is determined as changes in the price of services relative to the producer price index of final industrial goods. The econometric results are generated using the Johansen cointegration method, on a country-by-country basis, and using panel cointegration tests for the group of countries. Significant and correctly signed productivity effects are reported for this group of countries with respect to both the internal price ratio and also the CPI-based real exchange rate. In sum, significant and correctly signed effects of productivity effects on the internal price ratio and on the real exchange rate are reported.

In this section we have discussed the potential impact demand- and supply-side effects can have on the real exchange rate. We now explore the relationship between these variables for a group of accession countries. Having done so, we then draw out the policy implications of our findings in a concluding section. 


\section{Data Description and Estimation Methods}

The countries considered in this study are Estonia, Hungary, the Slovak Republic and Slovenia. Austria serves as the foreign, or numéraire, country. The choice of Austria as numéraire reflects the fact that it is geographically very close to Hungary, Slovenia and the Slovak Republic (it has a common border with these countries), has close trading links with these countries and is structurally very similar to the German economy, which is their main trading partner. The data frequency is quarterly, and the time series dimension differs across countries and variables. However, we have constructed a balanced panel from the individual countries for the first quarter of 1995 to the first quarter of 2001. Apart from the interest rates, all of the data are in constant prices and are transformed into a base index with 1995:1Q $=100$. All time series, apart from the real interest rates (RIR) and net foreign assets (NFA), have been seasonally adjusted using an X-11 filter, and apart from the interest rates, all data have been transformed by taking natural logarithms. Data on NFA and interest rates are taken from the IMF's International Financial Statistics CD-ROM, while data on Austrian interest rates are sourced from the OeNB. All other data were obtained from the respective central banks or statistical offices.

We use two key dependent variables in our study. The first is the internal price ratio, Lrp100nta, the price index of nontradables relative to the price index of tradables. For this measure, tradables comprise the following categories: food and nonalcoholic beverages, alcoholic beverages and tobacco, clothing and footwear, transport and communication. Nontradables comprise the following categories: housing, household goods, health, recreation and entertainment, miscellaneous goods and services. ${ }^{5}$ The second dependent variable is the index of the CPI-based effective long-run equilibrium real exchange rate (LRER). We have constructed this index so that an increase implies an appreciation of the real exchange rate.

The key independent variable used in our study is productivity in the tradable relative to the nontradable sector. We use labor productivity as a proxy for marginal total factor productivity; it is calculated by dividing value added, or GDP, by employment in the respective sector. The tradable sector includes the following categories: agriculture, hunting and forestry; fishing; mining and quarrying; manufacturing, transport and

\footnotetext{
5

For Hungary tradables contain the category "goods total," i.e. food and alcoholic beverages, tobacco, clothing and footwear, consumer durable goods, other goods including motor fuels and lubricants. Nontradables contain the category "services total," i.e. repairs, clothing and footwear, rent, services for dwellings, household services, personal care and health services, transport services, communication, cultural, educational and entertainment services, gambling, membership, recreational services, other services.
} 
communication. The nontradable sector includes the following categories: electricity, gas and water supply; construction; wholesale and retail trade; hotels and restaurants; financial intermediation; real estate, renting and business activities; public administration and defense; education, health and social work; other community; and social and personal activities.

Due to the lack of more disaggregated data for Hungary, tradables contained mining and quarrying; manufacturing and electricity; transport, storage and communications. Nontradables for Hungary comprised construction; trade; repair; hotels and restaurants; financial intermediation and real estate activities; public administration; education, health and social work; other community; social and personal service activities. For Slovakia, the tradable sector contains agriculture;, mining and quarrying; manufacturing and transport; storage and communication; while the nontradables, in turn, consist of electricity, gas and water supply; trade; repair of motor vehicles, and other services.

Our constrained productivity measure is labeled Iratna, and the unconstrained measures are Irata (productivity in tradables) and Irana (productivity in nontradables). To evaluate the role of the distribution sector we use labor productivity in that sector (wholesale and retail sales). Data availability means that this variable can only be calculated for Estonia and Slovenia. In any estimation involving that sector, we exclude the distribution sector from nontradables.

The demand-side variables included as explanatory variables are: consumption as a proportion of GDP; private consumption as a proportion of GDP; total consumption as a proportion of GDP. For Slovenia, quarterly data on consumption are only available from 1999. Therefore, to construct a quarterly series for the period before 1999, we have extrapolated the annual values. The final set of explanatory variables involve regulated prices.

As noted above, our empirical tests are conducted for a panel of four countries. Recent developments in the econometrics of panel data sets has sought to address the potential nonstationarity of the series entering the panel. In particular, McKoskey and Kao (1998), Pedroni (1997) and Phillips and Moon (1998) have proposed panel equivalents to the single equation fully modified estimator while McKoskey and Kao (1998) and Mark and Sul (1999) have proposed using a panel dynamic ordinary least squares (DOLS) estimator. Since Kao and Chiang (1999) have demonstrated that the panel DOLS procedure exhibits less bias than the panel ordinary least squares OLS and panel fully modified estimators and Mark and Sul (1999) have emphasized the tractability of the estimator, we employ a panel DOLS estimator for all our regressions. 
A version of the panel DOLS estimator which allows for limited heterogeneity in the form of fixed effects is:

$$
y_{i t}=\theta_{1 i}+\theta_{2 t}+\theta_{3} x_{i t}+\sum_{j=-p}^{+n} \theta_{4 j} \Delta x_{i t+j}+\omega_{i t},
$$

where $y_{i t}$ is a scalar, taken to be either Irpnta or LRER in our application, $x_{i t}$ is a vector of explanatory variables, discussed above, with dimension $k, \theta_{1 i}$ is an individual fixed effect, $\theta_{2 t}$ is a time effect, $\theta_{3}$ represents a vector of coefficients, $p$ is the maximum lag length, $n$ is the maximum lead length and $\omega$ is a Gaussian vector error process. The leads and lags of the difference terms are included to ensure that the error term is orthogonalized. Our representation of the panel DOLS estimator assumes that the dynamics are the same across individuals.

\section{Empirical Results}

\subsection{The Baseline Model and the Balassa-Samuelson Effect}

In this section we consider the effect of the Balassa-Samuelson term on the internal price ratio and on the CPI-based real exchange rate. For example, in the first column of table 1 we report results from the panel DOLS regression of the internal price ratio (Irpnta) onto the constrained Balassa-Samuelson effect. The point estimate is correctly signed and strongly significant. The magnitude of the coefficient on the BalassaSamuelson effect, although numerically below the magnitude of the expenditure share on nontraded goods, is nonetheless insignificantly different from this expenditure share. The unconstrained coefficients reported in column 2 are correctly signed, strongly significant and of a plausible magnitude. The unconstrained estimates show that the coefficient on tradable productivity is much larger than the coefficient on productivity in nontradables, and indeed the hypothesis that they are equal and opposite is clearly rejected. This would seem to be evidence against a BalassaSamuelson interpretation of the effect of productivity and favor the MacDonald and Ricci (2002) interpretation. Columns 3 and 4 show that the constrained and unconstrained Balassa-Samuelson terms have a similar effect on the CPI-based real exchange rate (LRER).

In columns 5 and 6 we incorporate the constrained and unconstrained BalassaSamuelson terms into a regression for the CPI-based real exchange rate containing both relative net foreign assets as a proportion of GDP and the real interest differential as explanatory variables. These variables are seen as key variables in explaining systematic movements of real exchange rates (see MacDonald, 1999), and we include 
them here to ensure that the effects of the Balassa-Samuelson effect on the real exchange rate are not spurious. In accordance with theory, the coefficient on both NFA and RIR is expected to be positive. Note that coefficients on the BalassaSamuelson terms are similar, in terms of significance and sign, to the regressions where NFA and the real interest differential are not included, although the magnitude of the coefficent on Irata is different. Note also that the NFA and RIR terms are themselves correctly signed and statistically significant.

The last three columns contain the results from regressing the real exchange rate on various permutations of the two macrovariables. The sign, magnitude and significance of the coefficients in these regressions are similar to the regressions which include the macrovariables with the Balassa-Samuelson term, thereby confirming the robustness of our results. The unconstrained estimates of the Balassa-Samuelson effect contrast with that reported in MacDonald and Ricci (2002) for a panel of G-7 countries. They found that the coefficient on productivity in the tradable sector was smaller, in absolute terms, than the coefficient on nontradables. In the context of their model, MacDonald and Ricci rationalized this in terms of imperfectly substitutable traded goods and a home expenditure bias. We explain the opposite finding here in terms of an expenditure bias in favor of foreign goods.

\subsection{Demand-Side Variables and the Balassa-Samuelson Effect}

The first three columns of table 2 explore the effects of adding in the three demand variables - government consumption, private consumption and total consumption - in addition to the Balassa-Samuelson effect onto the internal price equation. As can be seen, the coefficients on the demand variables are similar across the three equations, each being approximately -0.1 . It is noteworthy that the coefficient on the BalassaSamuelson terms is unaffected by the introduction of the demand-side variables, and it would seem that the two variables coexist and have independent influences on the real exchange rate. Perhaps the most notable feature of the coefficient on the demand-side variables is that they have negative signs. This means they are wrongly signed in terms of the conventional effect referred to in section 3. Of course, as we have noted, the conventional (positive) sign presupposes that the law of one price holds. If it does not, and this is likely to be particularly so for the accession countries, then the negative sign is not entirely unexpected, since traded goods are more likely to be regarded as luxury goods in the accession countries than services are, which is the conventional assumption. However, the negative sign clearly has important 
implications for these countries as they catch up: some of the catching-up, by spilling over into the traded sector, is likely to make that sector uncompetitive.

However, when the demand-side variables are introduced into the internal price equation with the Balassa-Samuelson term unconstrained (columns 4, 5 and 6), the coefficients on the demand-side variables increase and become insignificant. The source of the insignificance of the demand-side variables in the unconstrained regressions would seem to stem from the collinearity of the variables. For example, the correlation coefficients between Iratna and each of the demand-side variables is around 0.1 in absolute terms; however, when the productivity variables are entered unconstrained, the correlation coefficient between the demand variables and Irana is between 0.4 and 0.5 in absolute terms. Qualitatively, the results for the internal price ratio are confirmed in the regressions for the $\mathrm{CPI}$-based real exchange rate. Here the coefficients on productivity, NFA and the real interest differential remain unchanged as demand-side variables are added in, although the coefficients on the demand-side variables are all insignificant.

In sum, the demand-side variables have a small, significantly negative effect on the internal price ratio and an effect on the CPI-based real exchange rate which is small and statistically insignificant.

\subsection{The Balassa-Samuelson Effect and the Wage Effect}

As we noted in section 3, the key channel through which the Balassa-Samuelson effect influences the overall CPI-based real exchange rate is through wages. Following MacDonald and Ricci (2001), we include wages in our regressions containing the Balassa-Samuelson effect. If wage are indeed the channel through which the Balassa-Samuelson effect operates, then their introduction should make the productivity term (s) insignificant. These results are presented in table 3 for both the internal price ratio and the overall CPI-based real exchange rate. The results for the overall real exchange rate are very interesting, since, as predicted by the BalassaSamuelson model, the coefficient on productivity becomes insignificantly distinguishable from zero. This finding contrasts sharply with the results in MacDonald and Ricci (2001) for the G-7. As we have noted, these authors find that when the relative wage term is introduced into a regression of the real exchange rate on relative productivity, the coefficient on productivity becomes significantly negative, and this can only be rationalized by using a non-Balassa-Samuelson.type framework. The result here seems to suggest that the Balassa-Samuelson interpretation of productivity is more relevant for the accession countries. 


\subsection{The Influence of Regulated Prices}

Deregulation of prices has been one of the main components of transition from central planning to market economies. For example, there is considerable empirical evidence that the adjustment of regulated prices played an important role in the inflationary process and in the development of relative prices in the transitional economies throughout the last decade (see e.g. Pujol and Griffith, 1998, and Wozniak, 1998). ${ }^{6}$ The cost recovery hypothesis developed by Zavoiko (1995) provides the most influential theoretical justification of this evidence.

So far, however, the importance of regulated prices in determining relative prices and real exchange rates in these economies has been analyzed separately from the Balassa-Samuelson effect. Our data set allowed us to address this problem and to analyze both effects simultaneously in order to gauge their relative importance. Table 4 reports the main results. Our regulated price term (Irpa) has a (highly) statistically positive effect on the internal price ratio and on the real exchange rate, irrespective of the specification considered. The point coefficient is high and in most cases ranges between 0.10 and 0.16 . Moreover, introducing the regulated price term significantly increases the model's explanatory power, and this would seem to confirm the importance of this variable for the relative price and real exchange rate developments in these countries.

Probably the most striking and the most interesting result of these estimates is that once the regulated price term is introduced into the model, the significance of the Balassa-Samuelson term vanishes. In particular, when regulated prices are introduced into the internal price equation jointly with productivity, the constrained BalassaSamuelson term becomes insignificantly distinguishable from zero. The same holds when we introduce the regulated price term into the macroequation with the real exchange rate as the dependent variable: the constrained Balassa-Samuelson term becomes statistically insignificant.

The results change somewhat when we use the unconstrained Balassa-Samuelson term: the coefficient on tradable productivity becomes much smaller compared to the benchmark Balassa-Samuelson model reported in table 1, although it still remains significant at the $1 \%$ level. Nontradable productivity, however, becomes insignificantly different from zero. The results are similar when we introduce the regulated price term

$6 \quad$ Administrative prices still have a share of approximately $13 \%$ to $24 \%$ in the accession countries' consumer basket. See Backé et al. (2002). 
into the macroequations for the real exchange rate, the only exception being that the estimate of tradable productivity is significant at the $10 \%$ level.

All in all, our results seem to suggest that the adjustment of regulated prices had an independent and possibly much stronger effect on internal price ratios and on real exchange rates in transitional economies than the Balassa-Samuelson effect did. This finding is important, given the fact that regulated prices still account for a high share of the accession countries' consumer basket, and many of them are still below the cost recovery level. ${ }^{7}$

\subsection{The Distribution Sector}

Following MacDonald and Ricci (2001), we experimented with including a proxy for productivity in the distribution sector into our regressions. For example, MacDonald and Ricci demonstrate that for the G-7 countries, the share of the distribution sector in value added was an average of $15 \%$ for the 10 OECD countries studied and its share in total employment was $19 \%$ for these countries. For the two countries for which we have access to distribution data, namely Estonia and Slovenia, the employment share of the distribution sector in 2000 was approximately $14 \%$ for both countries, while the sector's value added share came to $15 \%$ and $12 \%$, respectively. Given that a large proportion of inward FDI in the accession countries consists of investment in the distribution sector, these numbers seem set to rise over time.

The results from incorporating the distribution sector for Slovenia and Estonia are reported in tables 5 and 6. For Slovenia, the new Balassa-Samuelson terms are correctly signed and significant and of the same order of magnitude as in the panel regresssions. The distribution term has a significantly positive effect in the regression with a constrained Balassa-Samuelson term, but the effect is insignificant in the unconstrained Balassa-Samuelson regression, a finding we attribute to the collinearity among the series. For Estonia the Balassa-Samuelson terms are all statistically significant, although the coefficient on productivity of the nontraded sector becomes wrongly signed (suggesting that with the exclusion of the distribution sector, we are capturing a greater traded element in the nontraded sector). We note that the coefficient on distribution is correctly signed and significant in both the constrained and unconstrained cases. In the former, the coefficient on the Balassa-Samuelson term remains significant, as does the coefficient on productivity of the tradable sector

$7 \quad$ The share of regulated prices in the consumer basket in 2001 was $15 \%$ in Estonia, $18.5 \%$ in Hungary, $19.3 \%$ in the Slovak Republic (value for 2000 ) and $12.7 \%$ in Slovenia (value for 2000). See Backé et al. (2002). 
in the unconstrained regression (although the coefficient on nontraded production is insignificant). In sum, productivity in the distribution sector has an independent effect on the internal price ratio over and above that generated by the Balassa-Samuelson effect.

\subsection{Robustness Checks}

We also implemented all of the above-noted tests using a variety of other estimators, such as static OLS and DOLS with a correction for contemporaneous correlation. The application of these different estimators did not change the tenor of our results and they are therefore not reported here (but are available from the authors on request).

\section{Concluding Comments}

In this paper we have reexamined the effect of productivity differentials and demandside effects on the CPI-based real exchange rates and internal price ratios of a group of four accession countries. In contrast to other empirical studies of CEECs, we use new, and we believe superior, measures of both productivity and demand-side effects for these countries. Our tests were conducted for a panel of four countries, comprising Estonia, Hungary, the Slovak Republic and Slovenia. Among our main findings are: The effects of productivity in the traded and nontraded sectors on both real exchange rates and internal price ratios are statistically significant; the influence of demand-side effects on the two dependent variables (CPI-based real exchange rates and internal price ratios) is weakly negative; regulated prices are significant in our regressions and remove the significance of the relative productivity effect. We have demonstrated that productivity in the distribution sector has a significantly positive effect on the internal price ratios of Estonia and Slovenia. We now consider the policy implications of our results for the membership of our group of countries in EMU.

Recently some economists (see for example Gros, 2001) have advocated a relatively rapid movement by the current group of accession countries to full monetary union with the EU. In this view, catching-up is not deemed to be an important issue with respect to an accession country's competitiveness because it is seen as a purely supply-side phenomenon, and any inflation generated is regarded as benign in the context of a Balassa-Samuelson effect. Our results would seem to offer some support for this view in the sense that the inflationary implications of the Balassa-Samuelson effect would seem to be very small, in particular much smaller than those reported in other studies. For example, for the two fast-growing countries in our study (namely Hungary and Estonia) we calculate a Balassa-Samuelson effect-implied inflation 
differential (against the numéraire country, Austria) of only 0.5 percentage points to 0.6 percentage points, while for the remaining, slower-growing countries we obtain an inflation differential of around 0.2 percentage points (this partly reflects a low share of nontradable prices in the CPI indices of these countries). Indeed, a doubling of productivity growth still produces inflation differentials which are well within the Maastricht criteria. These inflationary effects are little changed when the effects of the demand side are added in. The negative coefficient of our demand term suggests, however, that such demand-side effects could have a potentially deleterious effect on competitiveness and therefore should not be neglected.

The other main conclusion to stem from our work is that the role of regulated prices has a much more significant effect on the real exchange rates and internal price ratios of our group of accession countries than the Balassa-Samuelson effect does. Therefore, in future discussions of the European monetary process for accession countries more weight should be given to the effect of regulated prices rather than the emphasis which has so often been placed on productivity effects, which seem to be relatively benign. 


\section{References}

Anthony, Myrvin and Ronald MacDonald. 1998. On the Mean reverting Properties of Target Zone Exchange Rates: Some Evidence from The ERM. In European Economic Review 42: 1493-1523.

-- 1999. The Width of the Band and Exchange Rate Mean Reversion: Some Further ERM-Based Results. Journal of International Money and Finance 18: 411-428.

Backé, Peter, Jarko Fidrmuc, Thomas Reininger and Franz Schardax. 2002. Price Dynamics in Central and Eastern European EU Accession Countries. OeNB Working Paper 61.

Betts, Caroline and Michael Devereux. 1996. The exchange rate in a model of pricing to market, European Economic Review 40: 1007-1021.

Bergstrand, Jeffrey H. 1991. Structural Determinants of Real Exchange Rates and National Price Levels: Some Empirical Evidence. American Economic Review (March): 325-334.

Chinn, Menzie and Lloyd Johnston. 1999. Real Exchange Rate Level, Productivity and Demand Shocks: Evidence from a Panel of 14 Countries. NBER Discussion Paper 5709.

Clark, Peter and Ronald MacDonald. 1999. Exchange Rates and Economic Fundamentals: A Methodological Comparison of BEERS and FEERS. In R. MacDonald and J. Stein (eds.). Equilibrium Exchange Rates. Amsterdam: Kluwer.

Clark, Peter and Ronald MacDonald. 2000. Filtering the BEER: A Permanent and Transitory Decomposition. IMF Working Paper WP/00/144.

De Gregorio, José, Alberto Giovannini and Holger Wolf. 1994. International Evidence on Tradables and Nontradables Inflation. European Economic Review 38: 1225-1244.

Dornbusch, Rüdiger. 1988. Purchasing Power Parity. In J. Eatwell, M. Milgate and P. Newman (eds.) The New Palgrave Dictionary of Economics. London: Macmillan: 1075-1085.

Égert, Balázs. 2002. Investigating the Balassa-Samuelson Hypothesis in Transition: Do We Understand What We See. Mimeo.

Engel, Charles. 1993. Real Exchange Rates and Relative Prices: An Empirical Investigation. Journal of Monetary Economics 32: 35-50.

Flood, Robert P. and Andrew K. Rose. 1995. Fixing Exchange Rates: A Virtual Quest for Fundamentals. Journal of Monetary Economics 36: 3-37.

-- 1999. Understanding Exchange Rate Volatility without the Contrivance of Macroeconomics. Economic Journal: F660-F672. 
Gros, Daniel. 2001. EMU, the Euro and Enlargement. In European CommissionEconomic Policy in the Framework of Accession to the European Union and Economic and Monetary Union.

Halpern, László and Charles Wyplosz. 1997. Equilibrium Exchange Rates in Transition Economies International Monetary Fund. Staff Papers 44 (4): 430-461.

-- 2001. Economic Transformation and Real Exchange Rates in the 2000s: The Balassa-Samuelson Connection. Mimeo.

Helpman, Elhanan and Paul Krugman. 1985. Market Structure and Foreign Trade. MIT Press.

Isard, Peter. How Far Can We Push the "Law of One Price"? American Economic Review 67 (December): 942-948.

Kao, Chihwa and Min-Hsien Chiang. 2000. On the estimation and inference of a cointegrated regression in panel data. Mimeo.

Kravis, Irving and Robert Lipsey. 1983. Toward an Explanation of National Price Levels. Princeton Studies in International Finance 52.

-- 1988. National Price Levels and the Prices of Tradables and Non-Tradables. American Economic Review (papers and proceedings) 78: 474-478.

Linder, Staffan Burenstam. 1961. An Essay on Trade and Transformation. New York: Wiley.

MacDonald, Ronald. 1999. Exchange Rate Behaviour: Are Fundamentals Important? Economic Journal 109: F673-F691.

-- 2000. Concepts to Calculate Equilibrium Exchange Rates: An Overview. Deutsche Bundesbank 3.

-- 2001. Some Exchange Rate Issues for the New Accession Countries: Comments and Reflections. In European Commission: Economic Policy in the Framework of Accession to the European Union and Economic and Monetary Union.

MacDonald, Ronald and Luca Ricci. 2001. PPP and the Balassa Samuelson Effect: The Role of the Distribution Sector. International Monetary Fund WP/01/38.

-- 2002. Purchasing Power Parity and New Trade Theory. International Monetary Fund WP/02/70.

McCoskey, Suzanne and Chihwa Kao. 1999. Comparing Panel Data Cointegration Tests With an Application of the Twin Deficits Problem. Mimeo.

Mark, Nelson and Donggyu Sul. 2001. Nominal Exchange Rates and Monetary Fundamentals: Evidence from a Small Post-Bretton Woods Panel. Journal of International Economics 53 (1): 29-52. 
Mussa, Michael. 1986. Nominal Exchange Rate Regimes and the Behaviour of Real Exchange Rates: Evidence and Implications. Carnegie-Rochester Conference Series on Public Policy 26.

Neary, J. Peter. 1988. Determinants of the Equilibrium Real Exchange Rate. American Economic Review 78: 210-215.

Obstfeld, Maurice and Alan M. Taylor. 1997. Nonlinear Aspects of Goods-Market Arbitrage and Adjustment: Hecksher's Commodity Points Revisited. Journal of Japanese and International Economies 11: 441-479.

Pedroni, Peter. 1997. Panel Cointegration: Asymptotic and Finite Sample Properties of Pooled Time Series Tests with an Application to the PPP Hypothesis (New Results). Mimeo. Indiana University.

Phillips, Peter and Hyungsik Moon. 1999. Linear Regression Limit Theory for Nonstationary Panel. Econometrica 67 (5): 1057-1111.

Pujol, Thierry and Mark Griffith. 1998. Moderate Inflation in Poland: A Real Story. In C. Cottarelli and G. Szapary (eds.): 197-229.

Rogers, John H. and Michael Jenkins. 1995. Haircuts or Hysteresis? Sources of Movements in Real Exchange Rates. Journal of International Economics 38: 339-360. Senik, Claudia. 2001. Economic policy and the exchange rate regime in a small open economy (like Lithuania). Mimeo.

Slok, Torsten and Mark De Broek. 2000. Focus on Transition Economies. IMF World Economic Outlook. (October).

Svensson, Lars. 1994. Why Exchange Rate Bands? Journal of Monetary Economics 33: 157-199.

Williamson, John. 1985. The Exchange Rate System. Washington D.C.: Institute for International Economics.

Wozniak, Przemyslaw. 1998. Relative Prices and Inflation in Poland, 1989-1997: The Special Role of Administered Price Increases. World Bank Working Paper 1897. Zavoico, Basil. 1995. A Brief Note on the Inflationary Process in Transition Economies. International Monetary Fund (July). 


\section{Appendix: Definitions and Notation of Variables}

\section{Country coding:}

_ee Estonia

_hu Hungary

_si Slovenia

_sk Slovak Republic

_aa Austria

\section{Variables:}

\section{a) Prices:}

Lp100nta - log of relative prices of nontradables to tradables, seasonally adjusted Lrpa - log of regulated prices, seasonally adjusted

Lrpnta - log of relative prices of nontradables to tradables, relative to the same variable in Austria, seasonally adjusted

\section{b) Productivity Variables:}

Latna - log of relative productivity in tradable sector to nontradable sector, seasonally adjusted

Latnas - log of relative productivity in tradable sector to nontradable sector, seasonally adjusted, corrected by labor shares

Lata - log of productivity in tradable sector, seasonally adjusted

Lana - log of productivity in nontradable sector; seasonally adjusted

Lratnas, Lratna, Lrata, Lrana - as above, but all relative to similar variables for Austria

Latnoda - log of relative productivity in tradable sector to nontradables sector, without the distribution sector, seasonally adjusted Latoda - log of productivity in tradable sector, without the distribution sector, seasonally adjusted 
Lanoda - log of productivity in nontradable sector, without the distribution sector, seasonally adjusted

Ladisa - log of productivity in distribution sector, seasonally adjusted

\section{c) Demand Variables:}

Lgcgdpa - log of government consumption over GDP; seasonally adjusted

Lpcgdpa - log of private consumption over GDP; seasonally adjusted

Ltcgdpa - log of total consumption over GDP; seasonally adjusted

Lcapitaa - log of GDP per capita, seasonally adjusted

Lrgcgdpa, Lrpcgdpa, Lrtcgdpa - the same but all relative to similar variables for Austria

From the above it follows that:

$\mathrm{L}-\log$

$\mathrm{p}-$ prices

a - productivity

a (at the end of the name) - seasonally adjusted

capita - GDP per capita

$\mathrm{t}$ - tradable

$\mathrm{n}$ - nontradable

gc - government consumption

pc - private consumption

tp - total consumption

gdpa - GDP, seasonally adjusted

rir - relative real interest rates

$r$ - relative variables

$\mathrm{rp}$ - regulated prices

od - without the distribution sector

s - corrected by labor shares 
Table 1 Basic Balassa-Samuelson Model and a Robustness Check

Estimation Method: PDOLS

\begin{tabular}{|c|c|c|c|c|c|c|c|c|c|}
\hline & Lrpnta & Lrpnta & LRER & LRER & LRER & LRER & LRER & LRER & LRER \\
\hline $\begin{array}{l}\text { NFA/GDP } \\
\text { (rnfagdpa) }\end{array}$ & & & & & $\begin{array}{l}0.00006^{* *} \\
(2.19)\end{array}$ & $\begin{array}{l}0.00004 \\
(1.18)\end{array}$ & $\begin{array}{l}0.00008^{* * *} \\
(2.77)\end{array}$ & 0.00004 & \\
\hline $\begin{array}{l}\text { Real interest } \\
\text { rates (rir) }\end{array}$ & & & & & $\begin{array}{l}0.005^{\star \star \star} \\
(3.87)\end{array}$ & $\begin{array}{l}0.004^{\star \star} \\
(2.039)\end{array}$ & \begin{tabular}{|l}
$0.008^{* \star *}$ \\
$(6.59)$ \\
\end{tabular} & & $\begin{array}{l}0.007^{* \star *} \\
(5.53) \\
\end{array}$ \\
\hline $\begin{array}{l}\text { Balassa- } \\
\text { Samuelson } \\
\text { effect (Iratna) }\end{array}$ & $\begin{array}{l}0.41^{\star * *} \\
(5.79)\end{array}$ & & $\begin{array}{l}0.15^{\star * \star} \\
(3.57)\end{array}$ & & $\begin{array}{l}0.42^{\star \star \star} \\
(4.63)\end{array}$ & & & & \\
\hline $\begin{array}{l}\text { Productivity in } \\
\text { tradables (Irata) }\end{array}$ & & $\begin{array}{l}0.51^{\star * \star} \\
(7.45)\end{array}$ & & $\begin{array}{l}0.72^{\star \star *} \\
(9.15) \\
\end{array}$ & & $\begin{array}{l}0.49^{\star \star *} \\
(3.26)\end{array}$ & & & \\
\hline $\begin{array}{l}\text { Productivity in } \\
\text { nontradables } \\
\text { (Irana) }\end{array}$ & & $\begin{array}{l}-0.23^{*} \\
(3.08)\end{array}$ & & $\begin{array}{l}-0.46^{* * *} \\
(5.33)\end{array}$ & & $\begin{array}{l}-0.43^{* * *} \\
(4.63)\end{array}$ & & & \\
\hline $\begin{array}{l}\text { Testing } \\
\text { restrictions on } \\
\text { Balassa- } \\
\text { Samuelson** }\end{array}$ & & & & & & & & & \\
\hline -Chi-square & & & & & & & & & \\
\hline -Probability & & & & & & & & & \\
\hline Adj. R-squared & 0.27 & 0.39 & 0.13 & 0.53 & 0.53 & 0.53 & 0.35 & 0.006 & 0.27 \\
\hline $\begin{array}{l}\text { Number of } \\
\text { observations }\end{array}$ & 100 & 100 & 100 & 100 & 100 & 100 & 100 & 100 & 100 \\
\hline
\end{tabular}

Estimations are in levels, ${ }^{*},{ }^{* *},{ }^{* * *}$ statistically significant at $10 \%, 5 \%$ and $1 \%$ level, absolute t-values in parentheses.

${ }^{* *}$ Wald Test on restrictions: $\mathrm{HO}$ : lata = -lana. 
Table 2 Basic Balassa-Samuelson Model, the Demand Side and a Robustness Check

Estimation Method: PDOLS

\begin{tabular}{|c|c|c|c|c|c|c|c|c|c|c|c|c|}
\hline & Lrpnta & Lrpnta & Lrpnta & Lrpnta & Lrpnta & Lrpnta & LRER & LRER & LRER & LRER & LRER & LRER \\
\hline $\begin{array}{l}\text { NFA/GDP } \\
\text { (rnfangdpa) }\end{array}$ & & & & & & & $\begin{array}{l}0.00006^{* *} \\
(2.04)\end{array}$ & $\begin{array}{l}0.00006^{* *} \\
(0.071)\end{array}$ & $\begin{array}{l}0.00006^{\star \star} \\
(2.02)\end{array}$ & $\begin{array}{l}0.00003 \\
(0.82)\end{array}$ & $\begin{array}{l}0.00004 \\
(1.04)\end{array}$ & $\begin{array}{l}0.00004 \\
(1.01)\end{array}$ \\
\hline $\begin{array}{l}\text { Real interest } \\
\text { rates (rir) }\end{array}$ & & & & & & & $\begin{array}{l}0.005^{* *} \\
(3.39)\end{array}$ & $\begin{array}{l}0.005^{* * *} \\
(3.67)\end{array}$ & $\begin{array}{l}0.005^{\star * \star} \\
(3.52)\end{array}$ & $\begin{array}{l}0.003 \\
(1.41)\end{array}$ & $\begin{array}{l}0.004^{*} \\
(1.78)\end{array}$ & $\begin{array}{l}0.004^{*} \\
(1.69)\end{array}$ \\
\hline $\begin{array}{l}\text { Balassa- } \\
\text { Samuelson } \\
\text { effect (Iratna) }\end{array}$ & $\begin{array}{l}0.42^{* \star *} \\
(5.97)\end{array}$ & $\begin{array}{l}0.43^{* * *} \\
(6.01)\end{array}$ & $\begin{array}{l}0.51^{* * *} \\
(6.59)\end{array}$ & & & & $\begin{array}{l}0.43^{* \star *} \\
(4.49)\end{array}$ & $\begin{array}{l}0.41^{* \star *} \\
(4.12)\end{array}$ & $\begin{array}{l}0.42^{* * *} \\
(4.27)\end{array}$ & & & \\
\hline $\begin{array}{l}\text { Productivity in } \\
\text { tradables (Irata) }\end{array}$ & & & & $\begin{array}{l}0.52^{* \star *} \\
(7.18)\end{array}$ & $\begin{array}{l}0.51^{\star * *} \\
(7.28)\end{array}$ & $\begin{array}{l}0.51^{* * *} \\
(7.26)\end{array}$ & & & & $\begin{array}{l}0.57^{* * *} \\
(3.22)\end{array}$ & $\begin{array}{l}0.51^{* \star *} \\
(3.1)\end{array}$ & $\begin{array}{l}0.52^{* * *} \\
(3.09)\end{array}$ \\
\hline $\begin{array}{l}\text { Productivity in } \\
\text { nontradables } \\
\text { (Irana) }\end{array}$ & & & & $\begin{array}{l}-0.21^{* \star} \\
(2.51)\end{array}$ & $\begin{array}{l}-0.21^{* *} \\
(2.45)\end{array}$ & $\begin{array}{l}-0.21^{* *} \\
(2.46)\end{array}$ & & & & $\begin{array}{l}-0.42^{* * \star} \\
(4.22)\end{array}$ & $\begin{array}{l}-0.40^{\star * *} \\
(3.88)\end{array}$ & $\begin{array}{l}0.41^{* \star *} \\
(4.02)\end{array}$ \\
\hline $\begin{array}{l}\text { Government } \\
\text { consumption/G } \\
\text { DP (Irgcgdpa) }\end{array}$ & $\begin{array}{l}-0.10^{* *} \\
(2.27)\end{array}$ & & & $\begin{array}{l}-0.003 \\
(0.06)\end{array}$ & & & $\begin{array}{l}0.004 \\
(0.07)\end{array}$ & & & $\begin{array}{l}0.06 \\
(0.89)\end{array}$ & & \\
\hline $\begin{array}{l}\text { Private } \\
\text { consumption/G } \\
\text { DP (Irpcgdpa) }\end{array}$ & & $\begin{array}{l}-0.13^{* *} \\
(2.03)\end{array}$ & & & $\begin{array}{l}-0.03 \\
(0.46)\end{array}$ & & & $\begin{array}{l}-0.04 \\
(0.6)\end{array}$ & & & $\begin{array}{l}0.006 \\
(0.07)\end{array}$ & \\
\hline $\begin{array}{l}\text { Total } \\
\text { consumption/G } \\
\text { DP (Irtcgdpa) }\end{array}$ & & & $\begin{array}{l}-0.11^{*} \\
(1.73)\end{array}$ & & & $\begin{array}{l}-0.01 \\
(0.28)\end{array}$ & & & $\begin{array}{l}-0.03 \\
(0.42)\end{array}$ & & & $\begin{array}{l}0.02 \\
(0.29)\end{array}$ \\
\hline \multicolumn{13}{|l|}{ Wald test* } \\
\hline \multicolumn{13}{|l|}{-Chi-square } \\
\hline \multicolumn{13}{|l|}{-Probability } \\
\hline Adj. R-squared & 0.28 & 0.27 & 0.24 & 0.37 & 0.37 & 0.37 & 0.51 & 0.51 & 0.51 & 0.51 & 0.50 & 0.50 \\
\hline $\begin{array}{l}\text { Number of } \\
\text { observations }\end{array}$ & 100 & 100 & 100 & 100 & 100 & 100 & 100 & 100 & 100 & 100 & 100 & 100 \\
\hline
\end{tabular}

Estimations are in levels, *, ${ }^{* *},{ }^{* * *}$ statistically significant at $10 \%, 5 \%$ and $1 \%$ level, absolute t-values in parentheses.

*Wald Test on restrictions: $\mathrm{HO}$ : lata $=$ lana $=($ demand variable $)=0$. 
Table 3 Introducing the Wage Effect. Estimation Method: PDOLS

\begin{tabular}{|c|c|c|c|c|c|c|}
\hline & LRPNTA & LRPNTA & LRER & LRER & LRER & LRER \\
\hline $\begin{array}{l}\text { NFA/GDP } \\
\text { (rnfangdpa) }\end{array}$ & & & & & $\begin{array}{l}0.00007^{\star \star \star} \\
(2.90)\end{array}$ & $\begin{array}{l}0.00005^{*} \\
(1.67)\end{array}$ \\
\hline Real interest rates (rir) & & & & & $\begin{array}{l}0.003^{* * *} \\
(3.40)\end{array}$ & $\begin{array}{l}0.003^{*} \\
(1.82)\end{array}$ \\
\hline $\begin{array}{l}\text { Balassa-Samuelson effect } \\
\text { (Iratna) }\end{array}$ & $\begin{array}{l}0.33^{* * *} \\
(3.47)\end{array}$ & & $\begin{array}{l}0.25^{* * *} \\
(2.91)\end{array}$ & & $\begin{array}{l}0.12 \\
(1.36)\end{array}$ & \\
\hline Productivity in tradables (Irata) & & $\begin{array}{l}0.45^{\star \star \star} \\
(4.76)\end{array}$ & & $\begin{array}{l}0.35^{\star \star \star} \\
(4.01)\end{array}$ & & $\begin{array}{l}0.17 \\
(1.26)\end{array}$ \\
\hline $\begin{array}{l}\text { Productivity in nontradables } \\
\text { (Irana) }\end{array}$ & & $\begin{array}{l}-0.19^{* *} \\
(2.06)\end{array}$ & & $\begin{array}{l}-0.15^{*} \\
(1.68)\end{array}$ & & $\begin{array}{l}-0.13 \\
(1.43)\end{array}$ \\
\hline Real wage (Irwea) & $\begin{array}{l}0.08 \\
(1.58)\end{array}$ & $\begin{array}{l}0.05 \\
(1.14)\end{array}$ & $\begin{array}{l}0.31^{* * *} \\
(6.48)\end{array}$ & $\begin{array}{l}0.29^{* * *} \\
(6.24)\end{array}$ & $\begin{array}{l}0.28^{* * *} \\
(6.21)\end{array}$ & $\begin{array}{l}0.27^{\star * *} \\
(5.87)\end{array}$ \\
\hline Adj. R-squared & 0.30 & 0.42 & 0.62 & 0.66 & 0.69 & 0.68 \\
\hline Number of observations & 100 & 100 & 100 & 100 & 100 & 100 \\
\hline
\end{tabular}

Estimations are in levels, ${ }^{*},{ }^{* *},{ }^{* * *}$ statistically significant at $10 \%, 5 \%$ and $1 \%$ level, absolute t-values in parentheses. 
Table 4 Basic Balassa-Samuelson Model, Regulated Prices and a Robustness Check Estimation Method: PDOLS

\begin{tabular}{|c|c|c|c|c|c|c|c|c|c|}
\hline & Lrpnta & Lrpnta & Lrpnta & LRER & LRER & LRER & LRER & LRER & LRER \\
\hline $\begin{array}{l}\text { NFA/GDP } \\
\text { (rnfangdpa) }\end{array}$ & & & & $\begin{array}{l}0.00001 \\
(0.36) \\
\end{array}$ & $\begin{array}{l}-0.00002 \\
(0.50)\end{array}$ & & & $\begin{array}{l}-0.00002 \\
(0.37)\end{array}$ & \\
\hline RIR & & & & $\begin{array}{l}0.006^{* * *} \\
(5.13)\end{array}$ & $\begin{array}{l}0.004^{* * *} \\
(2.53)\end{array}$ & & & $\begin{array}{l}0.006^{\star *} \\
(1.87)\end{array}$ & \\
\hline $\begin{array}{l}\text { Balassa- } \\
\text { Samuelson } \\
\text { effect (Iratna) }\end{array}$ & & $\begin{array}{l}0.07 \\
(1.05)\end{array}$ & & $\begin{array}{l}0.15 \\
(1.36)\end{array}$ & & $\begin{array}{l}0.43^{* \star *} \\
(4.42)\end{array}$ & & & \\
\hline $\begin{array}{l}\text { Productivity in } \\
\text { tradables (Irata) }\end{array}$ & & & $\begin{array}{l}0.17^{* * *} \\
(3.01)\end{array}$ & & $\begin{array}{l}0.26^{*} \\
(1.75) \\
\end{array}$ & & $\begin{array}{l}0.55^{* * *} \\
(5.61)\end{array}$ & & \\
\hline $\begin{array}{l}\text { Productivity in } \\
\text { nontradables } \\
\text { (Irana) } \\
\end{array}$ & & & $\begin{array}{l}0.10 \\
(1.88)\end{array}$ & & $\begin{array}{l}-0.14 \\
(1.26)\end{array}$ & & $\begin{array}{l}-0.29^{* *} \\
(2.87)\end{array}$ & & \\
\hline $\begin{array}{l}\text { Regulated } \\
\text { prices (Irpa) }\end{array}$ & $\begin{array}{l}0.16^{\star \star \star} \\
(11.78)\end{array}$ & $\begin{array}{l}0.14^{* \star *} \\
(8.26)\end{array}$ & $\begin{array}{l}0.14^{* * *} \\
(10.56)\end{array}$ & $\begin{array}{l}0.10^{* * *} \\
(3.57)\end{array}$ & $\begin{array}{l}0.10^{\star \star *} \\
(3.52)\end{array}$ & $\begin{array}{l}0.07^{* * *} \\
(2.97)\end{array}$ & $\begin{array}{l}0.07^{* * *} \\
(2.90)\end{array}$ & $\begin{array}{l}0.14^{\star * *} \\
(6.65)\end{array}$ & $\begin{array}{l}0.15^{\star * *} \\
(7.11)\end{array}$ \\
\hline Adj. R-squared & 0.62 & 0.62 & 0.77 & 0.63 & 0.62 & 0.49 & 0.55 & 0.62 & 0.38 \\
\hline $\begin{array}{l}\text { Number of } \\
\text { observations }\end{array}$ & 100 & 100 & 100 & 100 & 100 & 100 & 100 & 100 & 100 \\
\hline
\end{tabular}

Estimations are in levels, ${ }^{*},{ }^{* *},{ }^{* * *}$ statistically significant at $10 \%, 5 \%$ and $1 \%$ level, absolute t-values in parentheses. 
Table 5 The Role of The Distribution Sector in Estonia from 1994:1 to 2001:1 (OLS with White Heteroskedasticity Consistent Coefficient Covariance).

\begin{tabular}{|c|c|c|c|c|c|c|}
\hline & Lp100nta & Lp100nta & Lp100nta & Lp100nta & Lp100nta & Lp100nta \\
\hline $\begin{array}{l}\text { Balassa- } \\
\text { Samuelson } \\
\text { effect(out of } \\
\text { distribution) } \\
\text { (latnoda) }\end{array}$ & $\begin{array}{l}0.349^{* \star \star} \\
(5.30)\end{array}$ & & & & $\begin{array}{l}0.171^{* * *} \\
(2.69)\end{array}$ & \\
\hline $\begin{array}{l}\text { Productivity in } \\
\text { tradables (out } \\
\text { of distribution) } \\
\text { (latoda) }\end{array}$ & & $\begin{array}{l}0.371^{* * *} \\
(6.62)\end{array}$ & & $\begin{array}{l}0.245^{\star \star \star} \\
(3.79)\end{array}$ & & $\begin{array}{l}0.173^{* *} \\
(2.51)\end{array}$ \\
\hline $\begin{array}{l}\text { Productivity in } \\
\text { nontradables } \\
\text { (out of } \\
\text { distribution) } \\
\text { (lanoda) }\end{array}$ & & & $\begin{array}{l}0.70^{* * *} \\
(4.60)\end{array}$ & $\begin{array}{l}0.368^{*} \\
(1.83)\end{array}$ & & $\begin{array}{l}0.09 \\
(0.50)\end{array}$ \\
\hline $\begin{array}{l}\text { Productivity in } \\
\text { the distribution } \\
\text { sector (ladisa) }\end{array}$ & & & & & $\begin{array}{l}0.545^{* * *} \\
(8.35)\end{array}$ & $\begin{array}{l}0.401^{* *} \\
(2.38)\end{array}$ \\
\hline \multicolumn{7}{|l|}{$\begin{array}{l}\text { Testing } \\
\text { restrictions on } \\
\text { Balassa- } \\
\text { Samuelson }\end{array}$} \\
\hline -Chi-square & & & & & & 64.77 \\
\hline -Probability & & & & & & 0.000 \\
\hline Adj. R-squared & 0.26 & 0.55 & 0.49 & 0.61 & 0.72 & 0.75 \\
\hline $\begin{array}{l}\text { Number of } \\
\text { observations }\end{array}$ & 29 & 29 & 29 & 29 & 29 & 29 \\
\hline
\end{tabular}

Estimations are in levels, ${ }^{*},{ }^{* *},{ }^{* * *}$ statistically significant at $10 \%, 5 \%$ and $1 \%$ level, absolute t-values in parenthesis. Wald Test on restrictions: HO: lata = latoda $=$ lanoda = ladisa $=0$. 
Table 6 Distribution Sector in Slovenia from 1994:1 to 2001:1 (OLS with White Heteroskedasticity-Consistent Coefficient Covariance)

\begin{tabular}{|c|c|c|c|c|c|c|}
\hline & Lp100nta & Lp100nta & Lp100nta & Lp100nta & Lp100nta & Lp100nta \\
\hline $\begin{array}{l}\text { Balassa- } \\
\text { Samuelson } \\
\text { effect (out of } \\
\text { distribution) } \\
\text { (latnoda) }\end{array}$ & $\begin{array}{l}0.15^{\star \star *} \\
(11.12)\end{array}$ & & & & $\begin{array}{l}0.179^{* \star *} \\
(8.35)\end{array}$ & \\
\hline $\begin{array}{l}\text { Productivity of } \\
\text { tradables (out } \\
\text { of distribution) } \\
\text { (latoda) }\end{array}$ & & $\begin{array}{l}0.275^{\star \star \star} \\
(5.73)\end{array}$ & & $\begin{array}{l}0.204^{\star \star \star} \\
(5.74)\end{array}$ & & $\begin{array}{l}0.177^{* \star *} \\
(3.57)\end{array}$ \\
\hline $\begin{array}{l}\text { Productivity of } \\
\text { nontradables } \\
\text { (out of } \\
\text { distribution) } \\
\text { (lanoda) }\end{array}$ & & & $\begin{array}{l}-0.167^{* * *} \\
(-5.07)\end{array}$ & $\begin{array}{l}-0.12^{\star * *} \\
(-6.22)\end{array}$ & & $\begin{array}{l}-0.181^{\star *} \\
(-2.72)\end{array}$ \\
\hline $\begin{array}{l}\text { Productivity in } \\
\text { the distribution } \\
\text { sector (ladisa) }\end{array}$ & & & & & $\begin{array}{l}0.056^{*} \\
(1.83)\end{array}$ & $\begin{array}{l}0.59 \\
(0.733)\end{array}$ \\
\hline \multicolumn{7}{|l|}{ Dummy 97} \\
\hline \multicolumn{7}{|l|}{$\begin{array}{l}\text { Testing } \\
\text { restrictions on } \\
\text { Balassa- } \\
\text { Samuelson }\end{array}$} \\
\hline -Chi-square & & & & & & 115.30 \\
\hline -Probability & & & & & & 0.0000 \\
\hline Adj. R-squared & 0.78 & 0.52 & 0.53 & 0.80 & 0.80 & 0.80 \\
\hline $\begin{array}{l}\text { Number of } \\
\text { observations }\end{array}$ & 29 & 29 & 29 & 29 & 29 & 29 \\
\hline
\end{tabular}

observations

Estimations are in levels, ${ }^{*},{ }^{* *},{ }^{* * *}$ statistically significant at $10 \%, 5 \%$ and $1 \%$ level, absolute t-values in parenthesis. Wald Test on restrictions: $\mathrm{HO}$ : lata $=$ latoda $=$ lanoda $=$ ladisa $=0$. 
